\section{Godt om rettsmedisin}

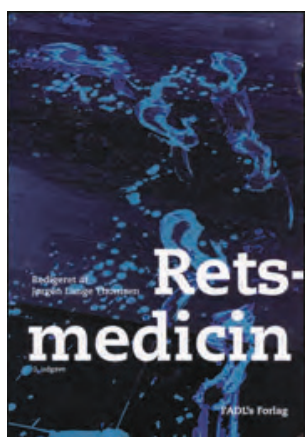

Jørgen Lange Thomsen, red.

Retsmedicin

3. utg. 446 s, tab, ill. København: FADL's

forlag, 2013. Pris DKK 650

ISBN 978-87-7749-714-8

Redaktøren, Jørgen Lange Thomsen, er lege og professor i rettsmedisin og jobber ved Syddansk Universitet i Odense, Danmark. Han har også utgitt andre bøker og publisert vitenskapelige artikler.

Retsmedicin er primært en pensumdekkende lærebok for medisinstudenter i Danmark. Den har 46 kapitler hvorav det overveiende antall dreier seg om rettspatologi og klinisk rettsmedisin. Under rettspatologi omtales rettsmedisinsk likundersøkelse og obduksjon, ulike dødsmåter og dødsårsaker. Under klinisk rettsmedisin omtales bl.a. voldtekt, seksuelle overgrep mot barn og tortur. Særlig beskrevet er funn av ulike former for vold/skader, og vurderingen av disse, dette også i lys av farlighetsgrad, hvilket ofte er relevant i klinisk rettsmedisin.

Mot slutten er det kapitler som omhandler andre underområder av faget, bl.a. rettsgenetikk og -toksikologi. Beskrevet er også de rettsmedisinske systemene i de nordiske landene, og selvfølgelig, siden boken er en pensumdekkende lærebok i Danmark, dansk lovgivning utfyllende i et eget kapittel. I denne tredje utgaven er det tilkommet nye kapitler om forskning og om samarbeidet med kriminalteknikere. Som tidligere har flere leger, overveiende fra nordiske land og med erfaring innenfor faget, bidratt til boken. Språket er enkelt og forståelig dansk. Det er flere illustrerende fargebilder og kasuistikker.

Rettsmedisin er medisin anvendt i rettens tjeneste, og på grunn av fagets nære relasjon til lovgivning utøves rettsmedisin noe forskjellig i ulike land. Innholdet begrenser seg etter min mening allikevel ikke til Danmark. Tvert imot gir den et godt grunnlag for rettsmedisinsk tankegang, som jo i hovedsak er lik på tvers av landegrensene. I lys av det kunne boken godt ha beholdt den tidligere undertittelen Nordisk lcerebog, og ved anskaffelse måtte man hva norsk lovgivning angår, søke annen litteratur. Språket bør være forståelig for nordmenn, og generelt også for ikke-medisinere. I tillegg til at boken er en lærebok ønsker forfatteren at den skal fungere som oppslagsverk og generelt nå en bred lesekrets. Det burde den kunne gjøre.

Alt i alt, for å konkludere: Anbefales!

\section{Hanna M. Eng}

Spesialist i patologi, Avdeling for rettspatologi og klinisk rettsmedisin Nasjonalt folkehelseinstitutt

\section{Mat som hjerneføde}

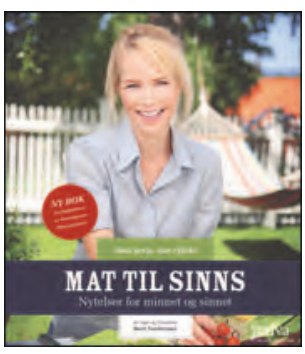

\section{Berit Nordstrand}

Mat til sinns

Nytelser for minnet og sinnet! 217 s, ill.

Oslo: Fraiva, 2013. Pris NOK 289

ISBN 978-82-999043-1-5
Berit Nordstrand er spesialist i klinisk farmakologi og har vist en spesiell interesse for kosthold, både $\mathrm{i}$ forebyggende og behandlende øyemed. Hun har tidligere skrevet en mer generell bok, Mat med mer, som undertegnede ga en god anmeldelse i Tidsskriftet (1). Hennes nye bok er ikke fullt så god.

Forfatteren sier innledningsvis at hennes nye bok har til hensikt å omsette vitenskapelige forskningsresultater til et folkelig språk, og at boken presenterer vanskelig tilgjengelig kunnskap for leseren med enkle historier, praktiske mattips og raske hverdagsretter.

Grunnen til at boken, etter min mening, ikke innfrir forventningene, er at forfatteren har gitt seg i kast med et meget innviklet og vanskelig tema, nemlig hvordan mat og kosthold påvirker vårt humør og vår hukommelse. Det er vel ganske sikkert at maten, måltidene og kostholdet påvirker både minnet og sinnet, men hvordan?

Fagfeltet er ikke helt enkelt å popularisere, verken metabolsk eller biologisk. Forfatteren prøver å forklare hvordan ulike signalstoffer dannes og virker. Hun lager ganske gode modeller for virkemåten. Men det blir for vanskelig for en leser som ikke har medisinske eller nevrobiologiske kunnskaper. Forklaringene blir dels for enkle, dels for kompliserte. Dessuten synes jeg det loves eller forventes for meget av næringsstoffenes innvirkning på vårt sentralnervesystem, og forfatteren mener at små grep har stor effekt. Jeg er enig $i$ at kostholdet spiller en rolle for vår sinnsstemning og hukommelse, men tror ikke det er så enkelt som det forfektes her.

Men når disse innvendingene er ført i marken, må jeg gi stor honnør til alle de gode rådene som gis om hverdagens kosthold. Spis mer naturlig mat, det vil si lag det meste av maten selv, og baser ikke det daglige kostholdet på ferdiglagde, matliknende produkter. Bruk mer fisk, både som hovedrett og som pålegg, og prøv å legge kostholdet over i en mer vegetabilsk retning. Og ikke minst: Hygg deg med matlagingen og rundt spisebordet.

Boken er full av gode oppskrifter, og det er gode og vakre bilder av både råvarer og ferdige delikate retter.

Kaare R. Norum

Professor emeritus, Avdeling for ernæringsvitenskap Universitetet i Oslo

\section{Litteratur}

1. Norum KR. God koke- og lærebok. Tidsskr Nor Legeforen 2013; 133: 675. 